\title{
The Medicalisation of Politics or the Politicisation of Medicine: The Case of Italian Struggles to Design Public Healthcare Institutions
}

Valeria Graziano is a theorist, organizer, and educator, currently a Research Associate at the Centre for Postdigital Cultures, Coventry University. She held BA in Fine Art and Art History (Goldsmiths College); MA in Visual Cultures (Goldsmiths College) and a Ph.D. in Critical Management Studies (Queen Mary University); Visiting Fellow at DCRL (Digital Cultures Research Lab) Leuphana University (DE) and at the John Hope Franklin Center, Duke University (USA). Her research focuses on cultural practices that foster a creative redistribution of social reproduction, the refusal of work, and the politicization of pleasure. She is one of the convenors of Pirate Care (https://pirate. care), a research process focusing on collective learning and disobedient responses to the current care crisis (2018- present).<valeria_graziano@yahoo.it> ORCID: 0000-0002-2666-8231
Abstract In the present article, we reflect on some key aspects for the design of public health systems by retracing the history of the Italian National Health Service, or Servizio Sanitario Nazionale (SSN), from its inception to the present days, analysing how a series of subsequent reforms and counter-reforms impacted its functions and services. Our reflection is based on a collective interview with Fulvio Aurora, Paolo Fierro and Edoardo Turri, three members of Medicina Democratica, which has been and continues to be one of the key organizations in the struggles for keeping health a public value in Italy. While our standpoint on the issue of health is geographically situated, we believe that an analysis of the Italian healthcare sector, with its successes and its failures, can offer important points of departures for identifying some key characteristics to shape contemporary approaches to healthcare design that can be translocal and cosmopolitan in their application.

Keywords Healthcare politics; Critical Medicine; Italian National Health Service (SSN); Medicina Democratica 


\section{A medicalização da política ou a politização da medicina: o caso das lutas italianas no design de instituições públicas de saúde}

Maddalena Fragnito is a cultural activist exploring the intersections between art, transfeminisms and technologies by focusing on practices of "commoning care". At the moment she is a Doctoral Student at Coventry University's Centre for Postdigital Cultures.

<vmaddalenafragnito@gmail.com> ORCID: 0000-0002-8670-0707
Resumo No presente artigo, refletimos sobre alguns aspectos fundamentais para o design dos sistemas públicos de saúde, retratando a história do Serviço Nacional de Saúde Italiano, ou Servizio Sanitario Nazionale (SSN), desde seu início até os dias atuais, analisando como uma série de reformas e contra-reformas subsequentes impactaram suas funções e serviços. Nossa reflexão se baseia em uma entrevista coletiva com Fulvio Aurora, Paolo Fierro e Edoardo Turri - três membros da Medicina Democrática - que foi e continua sendo uma das organizações-chave nas lutas para manter a saúde como um valor público na Itália. Embora nosso ponto de vista sobre a questão da saúde esteja geograficamente situado, acreditamos que uma análise do setor de saúde italiano, com seus sucessos e fracassos, pode oferecer importantes pontos de partida para identificar algumas características-chave, para moldar abordagens contemporâneas ao design de sistemas de saúde, que podem ser cosmopolitas em sua aplicação.

Palavras chave Política de saúde; Medicina crítica; Serviço Nacional de Saúde Italiano (SSN); Medicina Democrática

La medicalización de la política o la politización de la medicina: el caso de las luchas italianas por diseñar instituciones de salud pública

Resumen En el presente artículo, reflexionamos sobre algunos aspectos clave para el diseño de los sistemas de salud pública recorriendo la historia del Servicio Nacional de Salud italiano, o Servizio Sanitario Nazionale (SSN), desde sus inicios hasta la actualidad, analizando cómo una serie de Las reformas y contrarreformas posteriores afectaron sus funciones y servicios. Nuestra reflexión se basa en una entrevista colectiva con Fulvio Aurora, Paolo Fierro y Edoardo Turri, tres miembros de Medicina Democratica, que ha sido y sigue siendo una de las organizaciones clave en las luchas por mantener la salud como valor público en Italia. Si bien nuestro punto de vista sobre el tema de la salud está ubicado geográficamente, creemos que un análisis del sector de la salud italiano, con sus éxitos y sus fracasos, puede ofrecer puntos de partida importantes para identificar algunas características clave para dar forma a los enfoques contemporáneos del diseño de la atención médica que pueden ser translocal y cosmopolita en su aplicación.

Palabras clave Política sanitaria; Medicina crítica; Servicio Nacional de Salud de Italia (SSN); Medicina Democratica 


\section{Introduction: For a Health Internationalism}

The difference between institution and law: law is a limitation of actions, institution a positive model for action. (Deleuze, 2004:19)

The pandemic has brought the right to physical and mental health, understood as being simultaneously an individual and a collective issue, back to the centre of our lives. Mobilizations are starting again around such matters as access to quality care, in search of an overall renewal of welfare infrastructures and protocols, based on prevention and situated in the proximity of living and working places. Strengthening the networks of basic services and territorial assistance seems today paramount. The opposite has been taking place in recent years, which saw the progressive reinforcing of the private healthcare sector and the growing role of corporate welfare. In the context of recent struggles, a key insight has emerged insisting on how health cannot be seen as a matter confined to the national sphere alone. Rather, the Covid-19 pandemic has shown it must be tackled on a global scale. A key role is played by global actors - mostly nonprofit and private, but to a more limited extent, also public, such as the World Health Organization (WHO) - and therefore struggles need to intervene within such a global dimension of health in mind. Health, as well as political agency within it, as a question of scale, then.

For instance, the UK-based Care Collective declared in their recent manifesto:

The pandemic, in short, has dramatically and tragically highlighted many of the essential functions that are crucial for our web of life to be sustained: the labour of nurses and doctors, delivery drivers and garbage collectors. But it has also exposed how vital transnational alliances and co-operation are. [...] Thus, in order to 'scale up' our model of universal care to the global level, we need to foster transnational institutions, global networks and alliances based on the principles of interdependency and sharing resources, while embracing a democratic cosmopolitanism. [...] Caring capacities are shaped by nation states, but also transgress and extend beyond them. This means building new transnational institutions and intergovernmental organisations, agencies and policies whose organizing principles are based on care and caretaking and which can be reshaped according to care logics, not neoliberal capitalist logics. (CARE COLLECTIVE, 2020, p.153-156) 
Paraphrasing British geographer Doreen Massey, who famously asked "In what sense are 'regional' problems regional problems?" (1979), it would be significant to ask "in which sense is a 'scalar' problem a scalar problem?" (Brenner, 2001) as well as "in which sense is health a scalar problem?". At stake here there's more than praxeology, but the definition of a more intricate political horizon to determine how public services supporting health should be effectively designed and run in order to deliver health in an socially just, democratic, and sustainable manner. As defined by Anne Coote,

\footnotetext{
"services" are "collectively generated activities that serve the public interest. A service can be distinguished from a "good" as being a type of activity that is not separable from the producer and where production and consumption occur simultaneously. However, material goods and infrastructure are intrinsic to services in all areas of need. (COOTE, 2021, p.33)
}

Our way to engage with this question follows the contours of a conversation with Fulvio Aurora, Paolo Fierro and Edoardo Turri, three members of the Italian health activist organization Medicina Democratica, which will also function as the backbone of our account of the initial radical impetus and the later demise of the Italian public health system, the Servizio Sanitario Nazionale or SSN.

Through the focus on the Italian context, we wish to address a set of broader and interrelated questions around the design of public healthcare services and the scale of political agency which can be significant today across a number of struggles.

When reasoning around issues of health, and seeking for definitions that complexify this concept beyond a mere ensemble of optimal bodily functionality, the Italian context offers an effective standpoint. Not only because it was the first place where the pandemic spread beyond its original outbreak in the Chinese province of Wuhan, but also because in the Seventies this country has been a very important laboratory of political practices that contributed significantly to shape international debates and political imaginaries around healthcare practices. For example, one might recall the importance of Franco Basaglia's work for the so-called "anti-psychiatry" revolution; the invention of the consultori (a network of self-managed reproductive healthcare centres), operated by the feminist movement, which later become part of the national healthcare system; and finally, the method of the workers' self-inquiry introduced by activists such as Ivar Oddone and Giulio Maccacaro to launch important investigations into the toxicity of industrial plants, which were influential beyond the Italian borders. ${ }^{1}$ 
Fig 1. "L'Ambiente di Lavoro"pamphlet, p.4. Edited by FIM FIOM UILM, 1971.

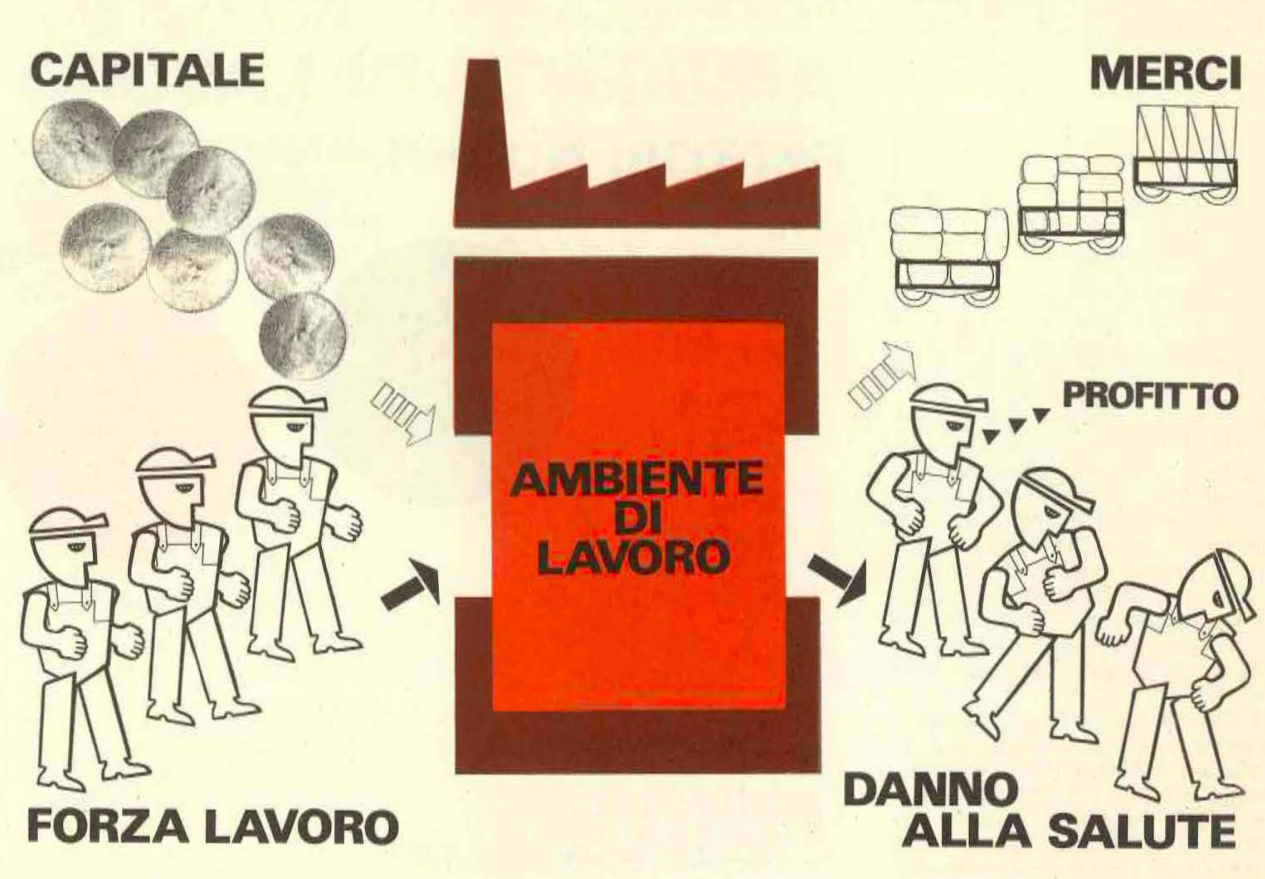

Which health?

The Covid-19 pandemic we are experiencing has shown how many cornerstones underpinning and the conceptualization of health and the provisions of care are flawed. While public health and territorial health have been systematically defunded and undercut in the last decades, it is now clear that no insurance company nor private service could address the impact of a virus as transmissible as Sars-CoV-2 (which, indeed, does not have a particularly high Rt, transmissibility index) in the slightest.

The systemic weaknesses in the capacity of care that we have seen emerging in this last year have highlighted the seriousness of a number of structural problems in the way the responsibility for general health is inscribed in institutional actions: a constant reduction of the resources allocated by public health (especially in the poorest countries, with a substantial stagnation in those middle income (DANIELS, 2016); a proliferation of public-private partnerships that seize public resources for a few groups of private suppliers; a weakening of basic care; the marginalization of preventive and epidemiological approaches as less profitable than interventionists approaches; the deterioration of healthcare sector working conditions and the rise of social and health inequalities.

To address these serious problems, attention is often paid to the potential of new practices made possible by the use of digital and bioengineering technologies. "Hypertech medicine" is often discussed as the fu- 
ture panacea, as it would allow bespoke solutions created on the bases of genomic sequencing that could offer effective treatment for a number of currently incurable diseases.

While the diagnostic and therapeutic possibilities introduced by biogenetic technologies undeniably represent a revolution within medical practice, there are serious doubts as to whether they might offer public health solutions that are inclusive and sustainably scalable for the needs of large populations. Much of this kind of medicine relies on extremely expensive infrastructures and tools, the quasi totality of which are privately owned. Moreover, according to the latest scientific literature, on the one hand

\footnotetext{
the enormous and continuous increase of [...] chronic diseases is essentially the consequence of [...] ever increasing environmental stressors; on the other hand, the increasingly probable and fearful pandemics from infectious diseases are also the consequence of dramatic environmental transformations taking place globally. And in both cases the key word is primary prevention, not molecular medicine. (BURGIO, 2016)
}

To counterbalance this emphasis on the technological discontinuities introduced within a specific approach to medical practice, it is meaningful to examining the current situation in the light of a minor (DELEUZE, GUATTARI, 1983) genealogy of health which, in the Italian context of the Seventies, mobilised a number of doctors, epidemiologists, activists and other public health workers precisely to assemble a notion of healthcare that was based on prevention, participation, territorial proximity of services and care for the environment. This movement was able, albeit for a very short season, "to affirm a vision that did not identify medicine with the fight against diseases and even less with the fight against microorganisms and viruses, but with the creation of better social, cultural and health conditions" (Ibid., p.13-33).

\section{A minor Italian genealogy}

After the United Kingdom created the NHS in 1948, Italy was the second country (outside of the socialist world) to implement a universal, public, free health service supported through collective taxation, called Servizio Sanitario Nazionale (SSN), in 1978. The history of public healthcare in Italy has often been hailed as a success, as Chiara Giorgi highlights, because "according to the 2017 OECD data, life expectancy at birth in Italy is 83.1 years, compared to the 80.9 years of the European Union average: but the total health expenditure per inhabitant is 2,483 euros, against 2,884 of the average EU (a 15\% gap)" (GIORGI, 2020). 
The 1978 reform which instituted the SSN was the outcome of over thirty years of struggles carried out by an ample coalition which saw a idiosyncratic alliance between left wing parties, trade unions, medical workers, students, feminist movements and health activists.

The Seventies were in Italy a decade of lively political experiences and experiments, with many radical practices of struggle and an unprecedented level of generalised political conflict in the social body. The events that led to the creation of a national health system must be understood in this context as the expression of a strong push from below (which had its roots in the partisan resistance against nazifascism) (GIOVANARDI, 1978) and, at the same time, of a profound, transformative aspiration of the entire social and institutional structure. In this dynamic, it was the autonomy of social reproduction that challenged those who managed institutions to reform and/or invent new ones.

Most crucially, for Aurora, Fierro and Turri, this political capacity of "coalition building", of consciously crafting "alliances"3 across otherwise distinct segments of the left political spectrum, as well as across different professional and non professional profiles, was crucial for ensuring the victory over a public healthcare system. In this process, the achievements of the labor parties and trade union and the pressures carried out by the movements (feminists, students, health activists, radical psychiatry, and so on), were accompanied by practices of de-institutionalization within the medical system (e.g. the closure of the asylums), but also by instituent processes capable of inventing new institutions, which were transformative of power relations and which could cope with healthcare needs that were unmet by the church, the family or the traditional state apparatus. The health debate opened up to new horizons and was able to intercept deeper demands for change across all of these institutions.

\section{Environment-workplace-body continuum $=$ a political concept of health}

The design of the SSN, centred as it was around a territorially-diffused, preventive and epidemiological approach, tried to respond to a radical new idea coming circulating in the Italian society of those years: the invention of health as a political fact, an integrated vision of "benessere" 4 (wellbeing) as a continuum of relations between the environment, the workplace and the body. The political understanding of health as an integrated fact was made possible both by the multiple actors within the struggles at the time, and by a new conception of the relationship between health professionals and patients (citizens). 
The Seventies brought a critical 'professional power' school: the studies on the role of professionals in the social organization and the division of labour multiplied (Caselli, 2020). Professionalization is described as a community of interests using particular strategies to establish boundaries and organizational structures based on strategies of closure and monopoly of the market. Two main aspects of professional power are put into crisis in those years: on the one hand, the "disabling dimension" (Illich et al., 1977) of professions, as the tendency to objectify one's non-professional interlocutor and to disown his experience and knowledge of himself and the world. On the other hand, the profession's class nature, its deep roots in the capitalist economic and social order and its role in reproducing it.

Studies over professions' social dimension are intertwined with the link between knowledge and power (Foucault, 1977). Disciplinary and biopolitical techniques, tangled with professionalization (doctors, psychiatrists, pedagogues), respond to an economic government over the population in the name of its well-being, which shapes social life through a multiplicity of knowledge and institutions.

Eliot Freidson focuses on the complexity and conflictual nature of the relationship between the doctor and the patient: the professional status and institutional organization of medical work must be read as tools in use by doctors to assert their authority (Freidson, 1988).

Disabling professions, a volume curated by Illich, draws into the monopoly that the professional holds and exercises in defining the patient's needs. These needs are read as the individual result of a professional structure, something far removed from the patient's experience and actual needs (Illich et al., 1977).

Erving Goffman reconstructs and analyzes life inside asylums, showing the process of objectification and depersonalization to which inmates are subjected through psychiatrists and nurses' professional practices. His contribution of a non-psychiatric, non-professional gaze allows us to observe the asylum as a social institution that produces and reproduces the disease it has to deal with. His work is rapidly translated in Italy by Franca and Franco Basaglia (Goffman; Basaglia and Ongaro Basaglia, 1968), and impacted the processes of redefining the concept of profession and professionalism in the psychiatric field through the experience of the asylum of Gorizia and Trieste directed by Franco Basaglia.

Basaglia and Ongaro Basaglia, taking up Gramsci's analysis of technicians and intellectuals, start questioning their role as doctors in contemporary society: legitimized by technology, they are involved in the process of oppression of the dominated class by the ruling class (Basaglia and Ongaro Basaglia, 1975). Professions and care institutions are read as instruments of fabrication of illness and exclusion (Basaglia, 1868). Together with Illich, they state how caring for patients often ends up strengthening their illness while guaranteeing the expert's authority who "treats" them. The Basaglian experience radically deconstructs the institution on a conceptual level. 
It dismantles its alienating dynamics to promote - in a continuous "undo" and "redo" - the experimentation and invention of "new institutions" capable of changing and learning through experience: to deconstruct the institution and the profession and to reassemble them, in order to reinvent the healthcare system.

In the same years of Basaglia, in Italy, the professional power was also put in crisis in other sectors. Relevant is the field of work medicine developed by Ivar Oddone's working group. In continuity with the workers' investigation, they developed in the 1970s a diverse collective that investigated health in the workplace. Their critique on the disabling dimension of professional power intertwines with a strong critique of capitalism on the horizon of its overcoming. They push towards an "enlarged scientific community" (Oddone et al., 1977) that includes the experiential knowledge of workers, fundamental for the understanding of the reality of the factory and its improvement. This collective knowledge, in fact, allowed significant advances in the scientific knowledge of health problems in the factory.

Giulio Maccacaro, the founder of Medicina Democratica, also bases the entirety of his research on the necessity to break the historical separation between the object (the worker) and the subject (the doctor) of medical knowledge. His point of departure was the need of identifying "the causes of the causes of diseases" (Maccacaro, 1976), the aetiology of malaise, a task that was not yet included in the training of the doctor who is taught that the disease does not arise from a mode of production that distributes risk to centralize profit, but from the improper choice of inappropriate individual behaviour. The controversy against this way of understanding medical sciences and their teaching led Maccacaro to clash with the academic establishment of those years. He brought documented accusations against the power system of health and science, referring to its servitude to capital and the resulting distortions in the doctor-patient relationship and in the correctness of health information.

All these experiences have contributed to questioning the expert knowledge and elaborating alternative models for the construction and use of knowledge and direct and participatory management of health. Moreover, the reconfiguration of the relationship between subject and object of knowledge has opened up new possibilities for mutual subjectivation and the legitimacy of society to demand the reduction of the asymmetry of knowledge and power. In this trajectory, we must read the claim of workers' right to obtain compulsory school licenses and the establishment of "150 hours for the right to education", introduced in Italy for the first time in $1973,{ }^{5}$ on the occasion of the renewal of the national contract for metalworkers. A contractual institution that guarantees employees a maximum number of hours of paid work permits to be used in projects and activities concerning their own personal training. This workers' conquest, although still active, has gradually faded over the years, remaining linked to the particular context of the seventies and its great mobilizations. 
Within this cultural turn and critique to the role of science and medicine and its role in the capitalistic society, Medicina Democratica, was founded in Bologna on 15-16 May 1976. The right to health, "a fundamental individual good and collective interest", brought together and weld student struggles with the workers' movement, researchers and health professionals, who questioned the responsibility of science and research in perpetuating the injustices of a class society. The recognition of the defence of the living environment became a natural extension of the class struggle conducted within the factory, in the need to use scientific construction as an inclusive tool of another, collective, participatory, democratic knowledge.

In the founding speech of the Medicina Democratica , Maccacaro analyzed the history of medicine from the perspective of the working class, spoke of the disease as a loss of participation, therefore, of the need for a democratization of research and of a renewal of science and medicine through new alliances, by explaining how two counter processes were at stake: first, the medicalisation of politics, done by the capitalist class and, second, the politicisation of medicine done by the working class (Maccacaro, 1976). The medicalisation of the social, collective and political malaise, Maccacaro states, is the capitalistic way of controlling and constricting a relational problem into an individualised and accidental disease. He concluded by addressing the urgency of a different training for doctors and health workers.

From there on, Medicina Democratica connected and pushed forward struggles bringing together an integrated conception of heath with the request for the renewal of existing medical studies and training for medical staff; prioritizing prevention and basic medicine; deinstitutionalizing assistance models of healthcare and territorializing medical services under popular control; recognizing health practices that originated from grassroots movements, such as feminists and workers' ones; theorising health as a unified system and envisioning and practicing new institutions as form of a constituent power for the refoundation of the healthcare sector through participation. All these principles will lead, a couple of years after the birth of Medicina Democratica, to the approval of three important healthcare reforms which for a short moment seemed to actualize the group's vision.

\section{Before the SSN}

In order to fully appreciate how innovative and political such conceptualizations of health and care were, it is useful to contrast them with what preceded them. As in many other countries, before the institution of the SSN, Italian populations would rely mostly on "casse mutue" (mutual aid societies) and "casse cooperative" (cooperative insurance funds) which, while being an achievement of the working class movement world-wide, 
in practice locked the right to health to "production and economic cycles". ${ }^{6}$ The institution of INAM - the National Institute for the insurance against diseases by the Fascist regime in 1943 confirmed the link between employment status and right to care (Giorgi, 2014). Not incidentally, the INAM system did not challenge the for profit nature of medical care, as doctors were paid by the number of consultations they would perform. For those out of work, the many unemployed rural populations who were displaced and uprooted from their traditional ways of life in the aftermath of WWII, the only available care services were those extended by "beneficenza" (religious institutes and charity) (IBID), ${ }^{7}$ which tied those provisions to specific belief systems and to the whim of individual donors. For the upper classes instead, the main referent for medical care was the "medico condotto" (the family doctor), ${ }^{8}$ who would typically visit patients in their homes and leave the arrangements around longer care needs to be arranged via the use of domestic help (a tendency that has made a comeback in recent years in Italy through the reliance on cheap, female, migrant, stay-at-home care labourers).

Fig 2. "Gazzetta Ufficiale della Repubblica Italiana" Newspaper, Cover, 28 December 1978.
Supplemento ordinario alla "Gazzetta Ufficiale, n. 360 del 28 dicembre 1978

Spedlztone in abbonamento postale - Gruppo $I$

GAZZETTA

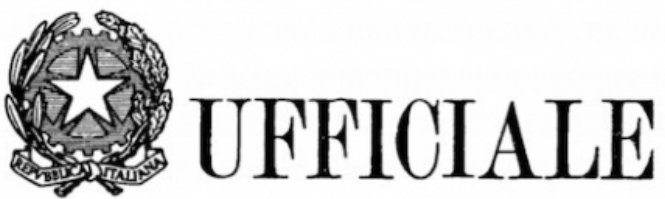

DELLA REPUBBLICA ITALIANA

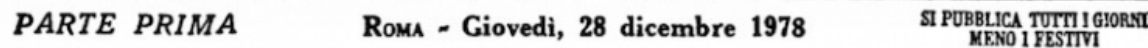

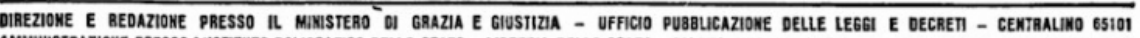

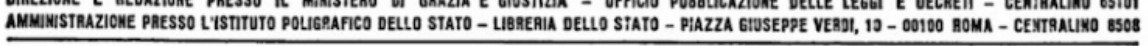

LEGGE 23 dicembre 1978, n. 833.

Istituzione del servizio sanitario nazionale. 


\section{Prevention and territoriality}

The foundation of the public healthcare system of 1978 then intervenes as an explosive disruption in a very entrenched system of medical care, whose interlocking pillars were in-work conditionality, bourgeois domesticity and religious piety. In contrast, the new SSN critically disjuncted the right to medical care from productivity and one's relations with an employer. Three reforms concurred to shape its new and radical system of values. First, law n.833 "turns the concept of assistance upside down" by "placing prevention at the forefront" ${ }^{10}$ of the medical system. A second law, n.194, ${ }^{11}$ greatly impacted the life of women as it grants the legal right to abortion for the first time. And finally, with law n.180, ${ }^{12}$ also known as "legge Basaglia", Italy resolves to become the first country in the world to shut the asylums, disavowing this oppressive institution as something unreformable, fundamentally incompatible with modern ideas of mental health and democratic life.

Seen from the point of view of institutional design, these three laws provided the scaffolding for an extremely vivacious period of instituent practices within the medical sector. In order to respond to the "prevention" mandate of the new healthcare system, a number of "servizi territoriali specifici, ${ }^{13}$ or locally-grounded care centres were established, born out of grassroots struggles. Among these, we find the first centres for the treatment of addictions and for the care of a pletora of mental health needs; centres for reproductive health and education (which partially overlapped with the centres for women's health established autonomously by the feminist movement); and finally a network of Centres for Health and Environment that monitored in an integrated fashion the health implications of environemntal and work conditions, de facto linkin for the first time in a public service the struggles for more humane and safe workplaces, the custodianship of the natural habitat and the responsibility towards our health as a collective good and a right.

These three laws, plus the measure that established the right of emergency hospital treatments already in $1948^{14}$, were the "four grand reforms ${ }^{15}$ that revolutionized healthcare in Italy after the war. Yet, as our interlocutors from Medicina Democratica highlighted, these reforms were not "in harmony with each other". In their eyes, the new healthcare system that emerged was rigged with contradictions and partial victories. They remarked how "Health, which should be conceived as a unitary concept, was instead unpacked in discrete segments. Medical culture has this tendency, it tends to follow an Aristotelic logic" and that "Perhaps this was our moment of weakness"16 in the process of modelling new institutional patterns for healthcare. 
A symptom of this failed amalgamation was the status of the hospital, an institution that had been reformed separately in 1968 via a law called "legge Mariotti" 17 that was criticized for maintaining an "hospitalocentric conception of healthcare", allowing the hospital to become "a structure that could be rapidly be converted into a firm that today has colonised its surrounding territory". ${ }^{18}$ As Ivan Cavicchi argued, despite the radicality of the initial instituent impetus, there is a residual "systemic invariance" (2013) at the heart of the Italian healthcare system, which, alongside the hospital, an institution that bears a profoundly military and religious imprint, still hinges upon a second conservative institution, embodied in the figure of the family doctor, the heir of a conception of medicine as a luxury service prevalent in previous centuries. The contemporary GP is in Italy a very problematic figure. Crucially, unlike doctors working in hospitals, family doctors are not public servants, but freelancers hired by the local healthcare units (with the contract ACN 2010 and 2018). Crucially, they are paid on the basis of the number of consultations and the number of patients registered with them. In short, in small communities, GPs are a cultural problem as they embed the interests of the local elites and often "functions as a bearer of votes", ${ }^{19}$ while in large urban centres they are at the centre of problems to do with a low quality of service, since a single doctor might be responsible for more than 1000 people in order to higher his or her income. ${ }^{20}$

\section{Counter-Reforms}

Not only the reforms, while radical, left the two crucial pillars of traditional medicine - the hospital and the family doctor - practically unscathed, but they were also undermined by a series of counter-reforms that begun to be introduced shortly after. During our conversation, the doctors had bitter words about this counter-reforming process. "Today" - they commented - "the propelling power of laws 180 and 194 has dwindled", while "law 833 never realized that overturning of the conception of healthcare, from cure to prevention". ${ }^{21}$

Already in 1979, the magazine of Medicina Democratica - still published today - sported a cover with the picture of a tombstone with the inscription: "Riforma Sanitaria in Memoriam 1978-1978" ('In memory of the healthcare reform 1978-1978'). In that issue, the activists of Medicina Democratica wanted to draw attention to the fact that not having abolished private healthcare, the new public sector was already compromised in its effectiveness. 
Fig 3. "Medicina Democratica", Magazine nr. 14/15, Cover, February-April 1979.

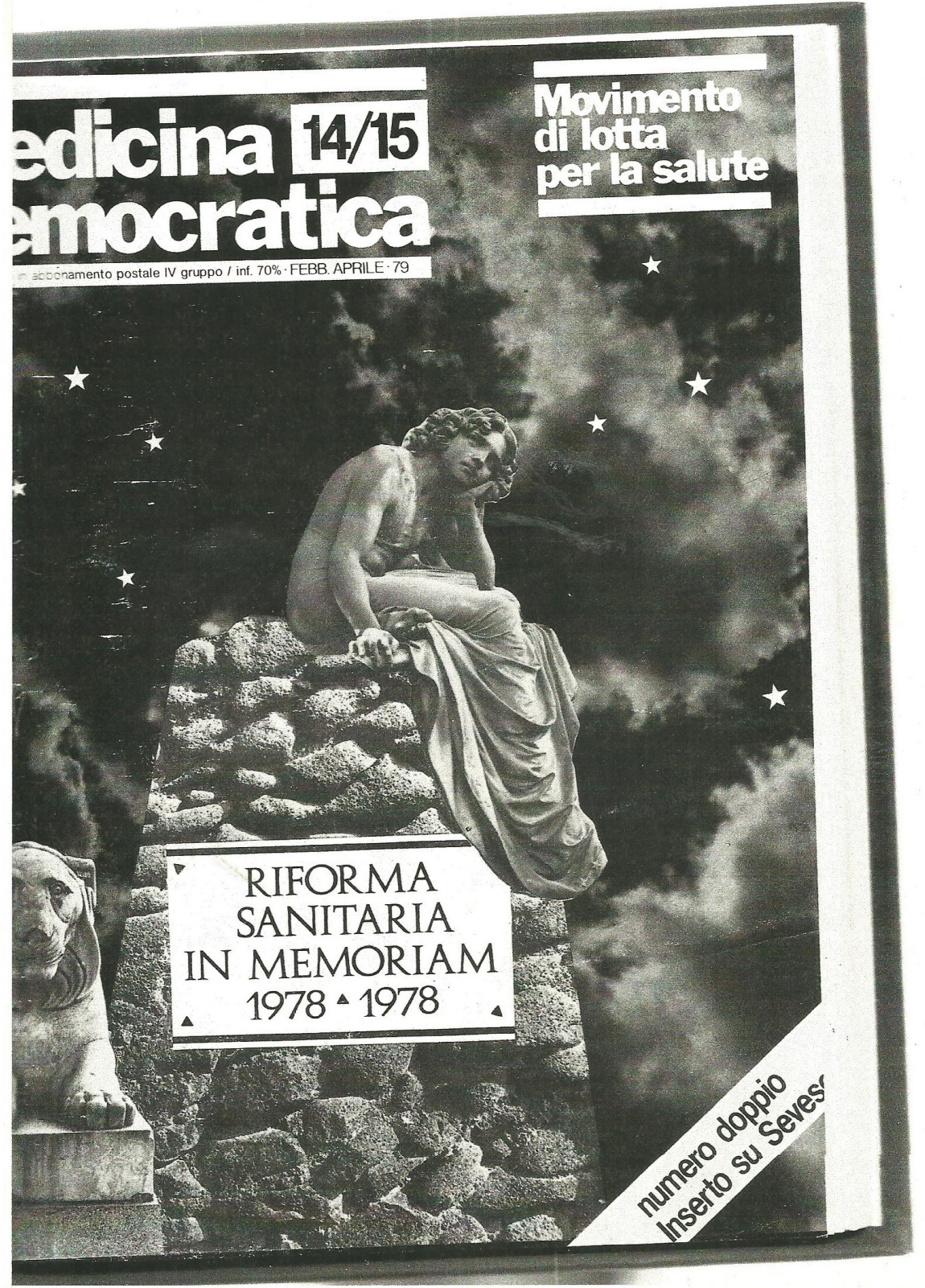

However, the structural counter-reform of the national health system began in 1992 (decree "De Lorenzo" n.502, followed by the law d.lgs.517/93) (COPPOLA, et al, 2008, p.6-7) introduced two new principles: "regionalization" and "aziendalizzazione".

The first reorganized medical provisions giving Regions "more and more autonomy and legislative powers in this field, so that they gained a substantial role in programming, organizing and managing health care services". ${ }^{22}$ Regions today function as a veritable "ministry of health for the ASL (local health authorities)", leaving "the relationship between central 
state and regions unresolved". ${ }^{23}$ While this was in part in line with the spirit of the 1978 foundational laws that sought to reduce the role of the central State to develop services of territorial proximity. In practices however, regionalization achieved the opposite of territoriality in terms of its politics of healthcare. Rather than boosting closeness with the life and work conditions of citizens, it de facto introduced the

possibility of a too deep fault of inequality as to what is offered in different regions beyond the threshold of what is established as essential at the national level and a too broad discretion in defining standards, procedures, guidelines, not to mention the burning issues of costs and quality. (SEMPLICI, 2014)

The second principle, that of "aziendalizzazione" merits some further unpacking. This word, of difficult translation in the English language, describes "the transition to a commercial model" a composite process that a recent judgment of the Court of Justice of the European Union described as

\footnotetext{
the transformation of existing 'local health units', which were originally administrative authorities operating at municipal level, into entities with legal personality and commercial autonomy, namely organisational, financial, accounting and managerial autonomy, which has led some legal writers and national case-law to classify public health entities, including hospitals, as 'public economic entities'. ${ }^{24}$
}

The process of aziendalizzazione is registered by a change of name of the basic units in which the healthcare system is organized, which at the beginning were called USL - unita' sanitarie locali (local healthcare units) - and later saw their name changed into ASL - aziende sanitarie locali. In practice, this move replaced the impetus towards a democratization of the mechanisms overseeing healthcare services, which in the reform of 1978 were managed by a Committee with citizens representatives, as well as representatives of the medical staff, and that it was suppressed to install a verticalist decision-making system, where executive decisions are in the hands of the Director General. From the perspective of our interlocutors from Medicina Democratica, this shift introduced a "bourgeois management of welfare", de facto excluding "those workers who had created that very welfare with their own struggles" 25 and who fought the hardest to obtain medical care for all in the first place. Inside the ASL "there are no democratic processes" 26 to speak of these days. The members of the executive board are nominated by the director general; while the medical council has been re- 
duced to a "consultative" role. For Aurora, Fierro and Turri, the modifications introduced in the original institutional design impact the attitude of users towards the service: "People's attitude today is vindictive; it is about reclaiming their rights, but in a rough manner. They think of themselves as clients". ${ }^{27}$

The combination of the two processes of regionalization and organizational transformation of the health centres to function more and more as private sector firms dismantled the effectiveness of many of the servizi territoriali, "giving a lot of power to regional governors and managers and very little autonomy to mayors (even though mayors are legally defined as the custodians of the health of citizens) and medical workers"28. "Municipalities should play an institutional role in healthcare, but in reality they do not". ${ }^{29}$ For example, the monitoring of citizens' health data, working conditions and environmental hazards is no longer performed together. Each of these areas is today the responsibility of a separate public entity, and these are not bound to coordinate their activities. The health and safety of workers is in the hands of "a doctor who is often connected with the employers" and "whose role is more that of a peace-keeper" 30 than an impartial arbiter of wrongdoings. Since contractual conditions have been fully privatized (a process already begun in 1981) ${ }^{31}$, many workers no longer dare to question the toxicity of their work places for fear of retaliation. The concepts of "harmfulness" and "toxicity" too have been reduced to the direct impact that a given industrial process might have upon workers' health, but the broader consequences of production for the environment and the surrounding communities are no longer taken into account. Meanwhile, the health of the environment has been placed in the hands of a dedicated agency, ARPA (Regional Environmental Protection Agency). Unlike its predecessor, this agency is not accessible to regular citizens however, but can only be contacted by municipalities who can ask for an intervention or to investigate a given situation. With bitter irony, the creation of such a new public institution dedicated solely to crimes of pollution was supported by various environmentalist groups; yet, ARPA paradoxically ended up having much less leverage than its predecessor upon the culprits of contaminants and natural disasters, who are often powerful industrialists. In short, the de-linking of public health, safety at work and protection of nature has resulted in a weakening of each of those areas of public intervention. 
Fig 4. Sit-in for the 194 law's approval, Archivio Rcs, 1978.

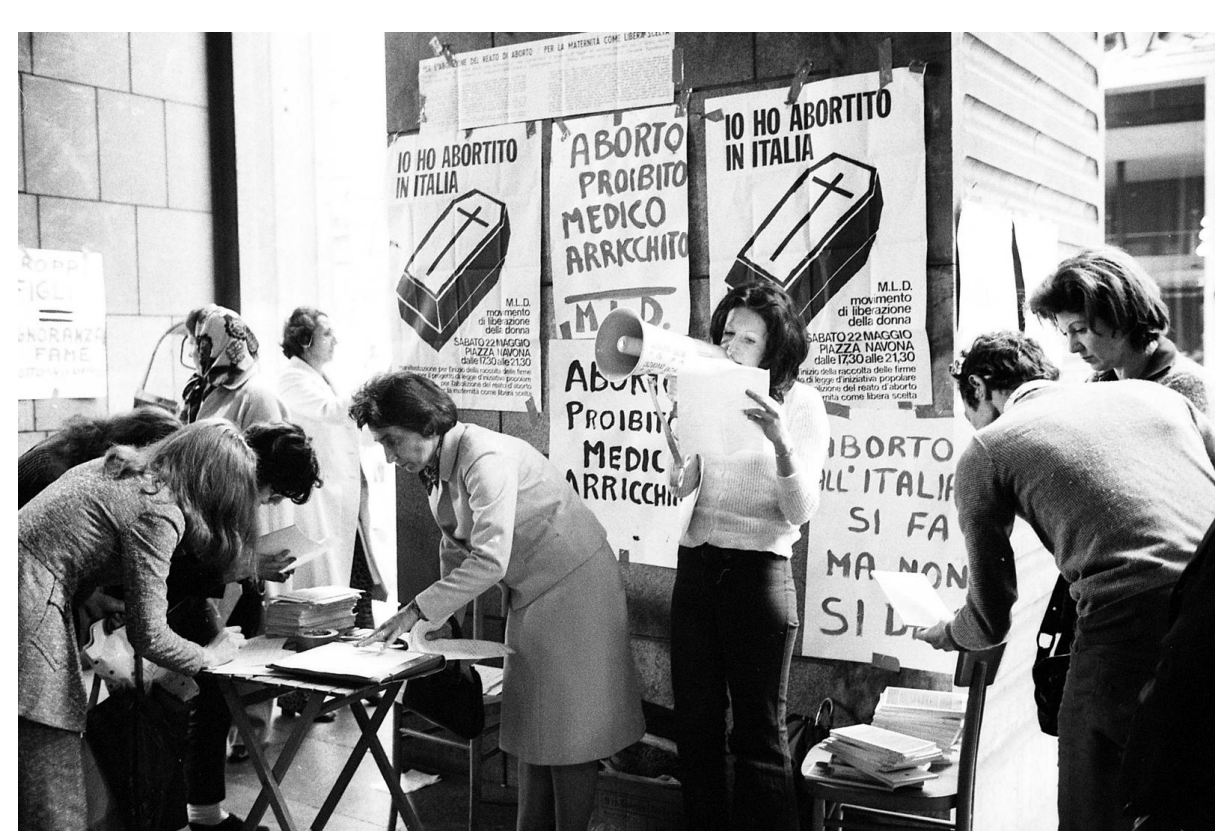

What Can Be Learned From Partial Revolutions?

The legacy of the health struggles of the Seventies and the political ethos that led to the design of a cluster of innovative healthcare institutions in Italy seems today compromised by the many counter-reforms that have chipped away much of its core values. Today and for many years in Italy, many treatments are paid out of pocket by the patients and more and more people need to rely on parallel services offered by public-private partnerships or the private sector tout court. Yet, as mentioned at the beginning, the country still has some interesting statistics that support the hypothesis that some of the legacy of social justice that animated Italians health struggles lives on in the professional cultures of some of its organizations, even when stripped of resources and reduced to their bare scaffoldings.

The conversation with Aurora, Fierro and Turri, kept coming back to a number of key themes that definitely anchor their professional as well as militant practice, and which bear meaningful implications for current speculations around the future of healthcare, particularly in the light of the Coronavirus pandemic, and especially important from the point of view of institutional design and the articulation of what kind of services and provisions would be worth fighting for.

In the course of our conversation some clear principles have emerged: the critique of professionalization of health as a specialist concern; the emphasis on preventive medicine; the necessity to intertwine the monitoring of production processes, health indicators and environmental data; the benefits of grounding services in territorial dynamics; the importance of democratic decision-making processes within each of the nodes of the services. In short, a composite and complex notion of health as a bio-social factor. 
During our dialogue Aurora, Fierro and Turri often noted the political specificity of the Seventies and they were careful to avoid any nostalgia in their reconstruction of events. Speaking of the USL as an achievement, impossible to replicate in the current political landscape, they joked: "we would have had no USL without URSS". ${ }^{32}$

While they were fully aware the difficulties of identifying clear, viable paths for defending and relaunching the role of public healthcare, our interlocutors ended our conversation with a reflection on one important contradiction they experience around health organizing: a vast majority of political initiatives these days immediately position themselves at the national or even international scale, a tendency exacerbated by the lockdown and the consequent hyper-reliance on social media and streamed events. "But if we are all busy holding the general assembly, the national assembly, the international forum, and so on, then who is there left to take care of organizing the local meet-up"? ${ }^{33}$ Indeed, the problem of scale we outlined at the beginning reemerges here once more. If health is dependent on its institutions, and if those are in turn determined by a given culture and by the capacity of mobilisation of the body politics, then to talk to colleagues, to engage people where they are at, remains an essential political form of care labour, addressed this time to the institution of healthcare itself. Anne Tsing's theory of friction explains this last principle well when she highlighted the need for any global, abstract idea to get 'engaged' in 'sticky locations' to get realised, which in turn affect how these abstractions circulate and get applied further. If the "particular is that which cannot grow" (TSING, 2005, p.9), then tending to particulars, to what constitutes the "territorial" specificity of a given territory, enacts an important political praxis of health.

Despite being extremely articulate about the political implications of each of the institutional dispositives that articulate the public health service, Aurora, Fierro and Turri were adamant that even the most ingeniously designed service can achieve very little in the absence of political struggles. "Without participation, there is no prevention", they commented. "There can't be any institutional project without a social process to accompany it" ${ }^{\prime 3}$. In the absence of popular participation, even well-meaning efforts to achieve greater health justice via the redesign of services and institutional procedures is reduced to a kind of "engineering", that is, "a mode of doing without politics" 35 . 
1 For their influence in Brazil, see: MUNIZ, H. P., et al. Ivar Oddone and his contribution to Worker's Health in Brazil. Revista Brasileira de Saúde Ocupacional, 2013, 38.128: 280-291

2 BURGIO, E., interview with Mauro Boarelli and Enzo Ferrara. La prima sin-pandemia. Gli Asini, 29 March 2021. https://gliasinirivista.org/la-prima-pan-sindemia/ . Our translation.

3 AURORA, F.; FIERRO, P. and TURRI, E. Conversation with the authors, 16 February 2021.

4 lbid.

5 "Art. 46. Diritto allo studio", accessed April 11, 2021, https://www.gazzettaufficiale.it/atto/ serie_generale/caricaArticolo?art.progressivo $=0$ \&art.idArticolo $=47$ \&art.versione $=1 \&$ art codiceRedazionale $=18$ A03878\&art . dataPubblicazioneGazzetta=2018-06-08\&art.idGruppo $=9$ \&art .idSottoArticolo $1=10$ \&art.idSottoArticolo=1\&art.flagTipoArticolo $=1$

6 AURORA, F.; FIERRO, P. and TURRI, E. Conversation with the authors, 16 February 2021.

7 Ibid.

8 Ibid.

9 "LEGGE 23 dicembre 1978, n. 833", accessed April 11, 2021, https://www.gazzettaufficiale.it/ eli/id/1978/12/28/078U0833/sg

10 AURORA, F.; FIERRO, P. and TURRI, E. Conversation with the authors, 16 February 2021.

11 "LEGGE 22 maggio 1978, n. 194", accessed April 11, 2021, https://www.gazzettaufficiale.it/atto/serie_generale/ caricaDettaglioAtto/originario?atto.dataPubblicazioneGazzetta=1978-05-22\&atto. codiceRedazionale $=078$ U0194\&elenco30giorni=false 12 "LEGGE 13 maggio 1978, n. 180", accessed April 11, 2021, https://www.gazzettaufficiale.it/ eli/id/1978/05/16/078U0180/sg

13 AURORA, F.; FIERRO, P. and TURRI, E. Conversation with the authors, 16 February 2021. 14 La costituzione italiana, "Articolo 32", accessed April 11, 2021, https://ms-mms.hubscuola. it/public/3266278/cdi-3270689/costituzione_italiana_commentata/costituzione_italiana_ commentata/articoli/art32.html
15 AURORA, F.; FIERRO, P. and TURRI, E. Conversation with the authors, 16 February 2021. 16 Ibid.

17 "LEGGE 12 febbraio 1968, n. 132", accessed April 11, 2021, https://www.normattiva.it/uri-res/N2Ls?urn:nir:stato:legge:1968;132

18 AURORA, F.; FIERRO, P. and TURRI, E. Conversation with the authors, 16 February 2021.

19 Ibid.

20 During the SARS-CoV-2 pandemic, the latter issue became clear as more and more patients had to push their GPs to stop their consultations to ensure the safety of all.

21 AURORA, F.; FIERRO, P. and TURRI, E. Conversation with the authors, 16 February 2021.

22 AURORA, F.; FIERRO, P. and TURRI, E. Conversation with the authors, 16 February 2021. 23 Ibid.

24 Court of Justice of the European Union, "Judgment of december, 182014 in the case no C-568/13", accessed April 11, 2021, https:// www.stradalex.com/en/sl_src_publ_jur_int/document/cjeu2014_C-568_13_57

25 AURORA, F; FIERRO, P. and TURRI, E. Conversation with the authors, 16 February 2021.

26 Ibid.

27 Ibid.

28 Ibid.

29 Ibid.

30 Ibid.

31 Giustizia Amministrativa, "La riforma Madia della Pubblica Amministrazione", accessed April 11, 2021, https://www.giustizia-amministrativa. it/riforma-madia

32 AURORA, F.; FIERRO, P. and TURRI, E. Conversation with the authors, 16 February 2021.

33 Ibid.

34 Ibid.

35 Ibid. 


\section{Referências}

BASAGLIA, F. L'istituzione negata. Milano: Club degli editori, 1985.

BASAGLIA, F; ONGARO BASAGLIA, F. Crimini di pace. Torino: Einaudi, 1975.

BRENNER, N. The limits to scale? Methodological reflections on scalar structuration. Progress in human geography, 2001, 25.4: 591-614.

BURGIO, E., interview with Mauro Boarelli and Enzo Ferrara. La prima sin-pandemia. Gli Asini, 29 March 2021. https://gliasinirivista.org/la-prima-pan-sindemia/

CARE COLLECTIVE, The. The care manifesto the politics of interdependence. [S.l.]: Verso, 2020. CASELLI, D. Esperti: come studiarli e perché. Bologna: Il Mulino, 2020.

CAVICCHI, I. Il riformista che non c'è: le politiche sanitarie tra invarianza e cambiamento. Bari: Dedalo, 2013.

COOTE, A. (2021) Universal basic services and sustainable consumption, Sustainability: Science, Practice and Policy, 17:1, 32-46,

COPPOLA, F. S.; CAPASSO, S.; RUSSO, L. Profili evolutivi del SSN Italiano: analisi e sintesi della produzione normativa dal 1978 ad oggi. In: XX Conferenza della Società Italiana di economia pubblica, Università di Pavia, Pavia, 2008.

DANIELS, N. Resource allocation and priority setting. In: Public health ethics: cases spanning the globe, 2016, 61-94.

DELEUZE, G. Desert Islands: and Other Texts, 1953-1974. (Semiotext(e) / Foreign Agents), 2004.

DELEUZE, G., GUATTARI, F., What is a minor literature?. Mississippi Review, 11(3), 1983. pp.13-33.

FOUCAULT, M. Microfisica del potere. Torino: Einaudi, 1977.

FREIDSON, E. Profession of medicine: a study of the sociology of applied knowledge. Chicago [etc.]: The University of Chicago Press, 1988.

GIORGI, C. Le politiche sociali del fascismo. In: Studi storici, 2014, 55.1: 93-108.

GIORGI, C. Rediscovering the roots of public health services. Lessons from Italy. openDemocracy, 24 March 2020. https://www.opendemocracy.net/en/can-europe-make-it/rediscovering-roots-public-health-services-lessons-italy/

GIOVANARDI, A. La riforma Sanitaria del CLN del Veneto. Rome: Edizione delle Autonomie, 1978.

GOFFMAN, E.; ONGARO BASAGLIA, F.; BASAGLIA, F. Asylums: le istituzioni totali. Torino: Einaudi, 1968.

ILLICH, I., et al. Disabling professions. London: Boyars, 1977.

MACCACARO, G. A. Medicina Democratica, movimento di lotta per la salute. Maccacaro GA. Medicina e Potere: per una medicina da rinnovare. Scritti, 1966, 1976.

MASSEY, Doreen. In what sense a regional problem?. Regional studies, 1979, 13.2: 233-243. MUNIZ, H. P., et al. Ivar Oddone and his contribution to Worker's Health in Brazil. Revista Brasileira de Saúde Ocupacional, 2013, 38.128: 280-291.

ODDONE, I.; RE, A.; BRIANTE, G. Esperienza operaia, coscienza di classe e psicologia del lavoro. Torino: G. Einaudi, 1977.

SEMPLICI, S. The right to health-care and the regionalization of the health-care system. In: Italian journal of pediatrics. BioMed Central, 2014.

Recebido: 15 de fevereiro de 2021. Aprovado: 05 de março de 2021.
TSING, A. L. Friction: an ethnography of global connection. Princeton : Princeton University Press, 2005. 